\title{
Recent findings of wild European flat oysters Ostrea edulis (Linnaeus, 1758) in Belgian and Dutch offshore waters: new perspectives for offshore oyster reef restoration in the southern North Sea
}

\author{
Francis Kerckhof ${ }^{1, *}$, Joop W.P. Coolen ${ }^{2,3}$, Bob Rumes ${ }^{1} \&$ Steven Degraer ${ }^{1}$ \\ ${ }^{1}$ Royal Belgian Institute of Natural Sciences, Operational Directorate Natural Environment, Aquatic \\ and Terrestrial Ecology, Marine Ecology and Management, Gulledelle 100,1200 Brussel $\& 3^{\text {de }}$ en $23^{\text {ste }}$ \\ Linieregimentsplein, 8400 Oostende, Belgium. \\ ${ }^{2}$ Wageningen Marine Research, P.O. Box 57, 1780 AB Den Helder, the Netherlands. \\ ${ }^{3}$ Wageningen University, Chair group Aquatic Ecology and Water Quality Management, \\ Droevendaalsesteeg 3a, 6708 PD Wageningen, the Netherlands. \\ *Corresponding author: fkerckhof@naturalsciences.be
}

\begin{abstract}
The European flat oyster, Ostrea edulis, is an emblematic and ecologically important species that was fished to virtual extinction in Belgian and Dutch waters in the $19^{\text {th }}$ century. We report on recent findings of live specimens in Belgian and Dutch waters, an indication for the presence of O. edulis in these waters. Though small, these relict populations provide possibilities for natural recovery of O. edulis reefs in Belgian and Dutch waters, provided the oyster's habitat requirements are restored (e.g., exclusion of bottom disturbance). We suggest investigating whether a natural, yet slow, recovery using fisheries closures and gravel bed restoration is a feasible alternative to the currently envisaged human-mediated re-introduction of $O$. edulis in the North Sea. We identify and address the challenge of $O$. edulis detection and identification as an important issue blurring the true presence and distribution of oysters.
\end{abstract}

KEYWORDS. Coastal, subtidal, endangered species, restoration, recovery, benthos, invertebrates.

Kerckhof F., Coolen J.W.P., Rumes B. \& Degraer S. (2018). Recent findings of wild European flat oysters Ostrea edulis (Linnaeus, 1758) in Belgian and Dutch offshore waters: new perspectives for offshore oyster reef restoration in the southern North Sea. Belgian Journal of Zoology 148 (1): 13-24. https://doi.org/10.26496/bjz.2018.16

\section{Introduction}

The European flat oyster Ostrea edulis (Linnaeus, 1758) is an emblematic species that in the past occurred in huge numbers all along most of the European coasts (HOEK 1886; KORRINGA 1952; LAMBERT 1946; MÖBIUS 1877; OLSEN 1883) where it formed banks, so-called oyster reefs, a typical biotope known to harbour a high biodiversity (MÖBIUS 1877, 1893; VAN BENEDEN 1883; TESCH 1910) because of their ecosystem engineering features (BECK et al. 2011; BYERS et al. 2006). During the past century and a half, these beds declined massively (AIROLDI \& BECK 2007; KORRINGA 1946; VAN GINKEL 1996), such that in the Southern Bight of the North Sea natural populations have disappeared. The species 
and its habitat are now included on various lists of declining and threatened species (e.g., EC Habitats Directive (92/43/EEC); OSPAR 2009), and national actions towards its protection and restoration are being encouraged.

Prior to the $20^{\text {th }}$ century, $O$. edulis reefs were known to occur in several places in the North Sea (MöBIUS 1877; OLSEN 1883), including the Hinderbanks (Belgium: HOUZIAUX et al. 2008; LANSZWEERT 1868; VAN BENEDEN 1883) and the Oyster Grounds, a large bank northerly offshore from Terschelling (the Netherlands: MÖBIUS 1877; TESCH 1910). Oysters have always been harvested for food, but it was only from mid- $19^{\text {th }}$ century onwards that large scale industrial fisheries targeted these offshore reefs (HOEK 1886; KORRINGA 1946; MÖBIUS 1877; YONGE 1966).

English oystermen, for example, exploited the French part of the North Sea prior to 1862 and gradually moved into Belgian waters. Between 1868 and 1873 English oyster dredgers heavily exploited the Belgian oyster reefs to extinction ("Rapport sur l'administration et la situation des affaires de la ville d'Ostende" series available in the Municipal Archives of Oostende, Belgium). Gustave Gilson, aware of the exceptional biological richness of this site, investigated the Belgian oyster reefs between 1899 and 1910 (collection of the Royal Belgian Institute of Natural Sciences, RBINS). In that collection in the samples containing $O$. edulis, a large array of sizes, from recently settled spat to old specimens, was present (HouZIAUX et al. 2008). This indicates that at that time settlement and reproduction still occurred but at low levels, in the remnants of the former reefs. The last scientifically documented live $O$. edulis individual was collected by Gilson in 1933 (HouZIAUX et al. 2008) yet fishermen claim to have caught O. edulis in Belgian waters until 1946 (RAPPÉ 2008). Extensive scientific surveys undertaken since the 1970s (see e.g., CATTRIJSSE \& VINCX 2001) never reported live O. edulis in Belgian waters. The species can thus be considered virtually extinct in Belgian waters since about the mid-20 $0^{\text {th }}$ century.

In the Netherlands, local stocks had already declined as a result of intense fisheries before 1886 in most locations in and around the Wadden Sea (HoEK 1886). At that time, the far offshore Oyster Grounds still covered an area of approximately $27,000 \mathrm{~km}^{2}$ in Dutch and German waters (calculated after MöBIUS 1877 and OLSEN 1883). The spawning stock biomass of oysters must have been in the order of billions of individuals in the open North Sea (BERGHAHN \& RUTH 2005; DE VOOYs et al. 2004). However, with the onset of industrial fisheries, these stocks also started to decline (HoEK 1886). Dutch fishermen, for example, landed between 11 and 18 million oysters in the North Sea in 1889 alone (BERGHAHN \& RUTH 2005; DE VOOYS 2001). In the southern Dutch delta waters, oyster reefs were observed outside culture areas on the rock dumps at dikes, where trawling was prohibited (HoEK 1886). Today, some estuarine and coastal locations still have a natural oyster stock (SIKKEMA 2016), but offshore oysters are considered extinct (SMAAL et al. 2015).

Given its ecological importance and virtually extinct condition, O. edulis is considered a priority species for ecological restoration purposes on the North-East Atlantic Continental Shelf (e.g., ANONYMOUS 1999). In this paper we place recent findings of O. edulis specimens in Belgian and Dutch offshore waters into an historical context to speculate on the potential for a natural recovery of $O$. edulis reefs in the area.

\section{Material and methods}

Dedicated scientific diving campaigns, ship-based surveys and buoy inspections in search of hard substrate epifauna have been undertaken in various research projects in Belgium and the Netherlands since 2001 (Table 1, Fig. 1). The databases of these projects were screened for the presence of O. edulis. We verified the identification of the oyster specimens using internal and external morphological characters such as the presence of chomata differentiating the genus Ostrea from Crassostrea (STENZEL 1971; HARRY 1985; AMARAL \& SimONE 2014). The Belgian confirmed specimens of O. edulis were stored in pure ethanol, and lodged in the RBINS Marine Taxonomic Reference Centre's collection. We 


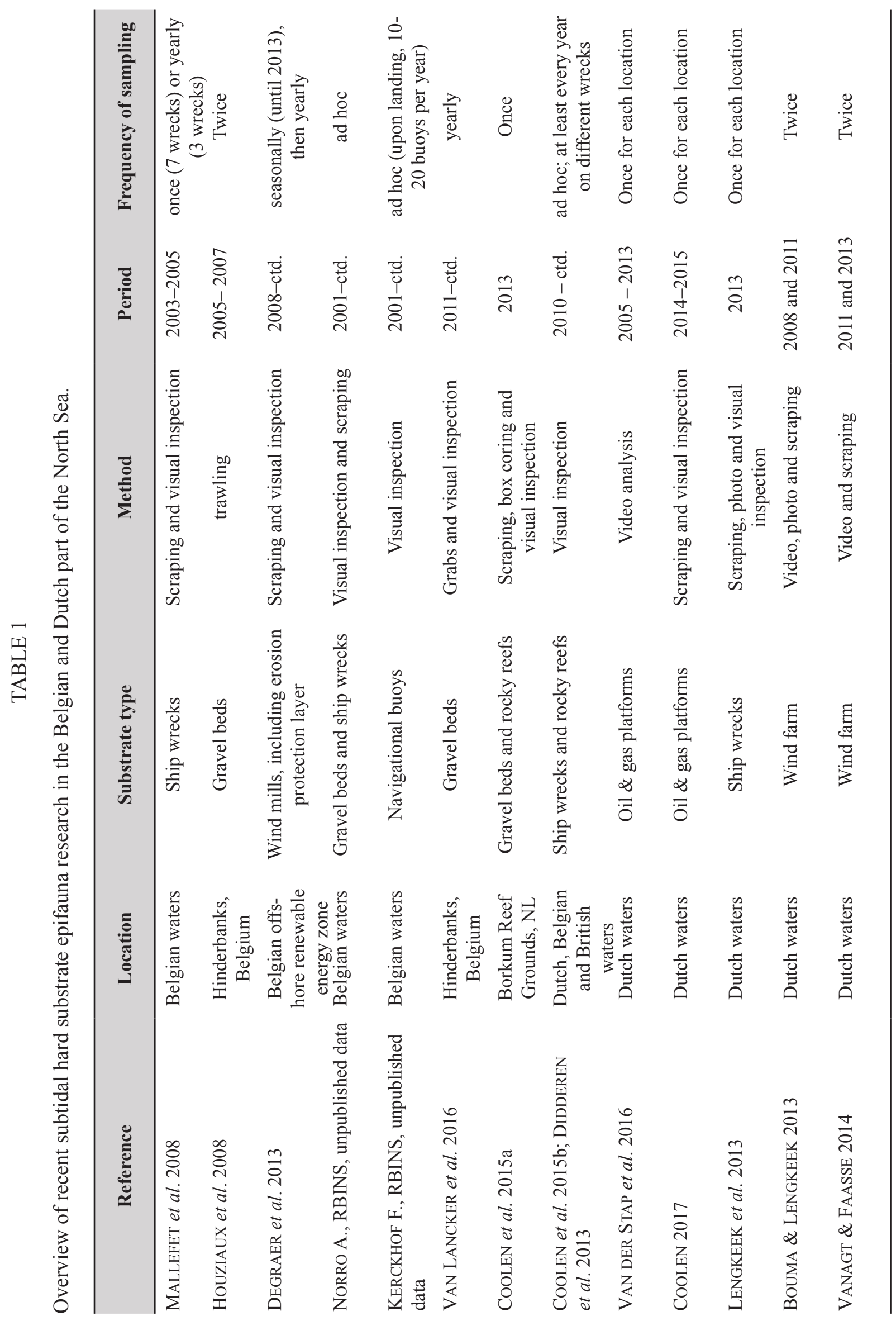


furthermore estimated the age of the Belgian specimens by counting the growth lines in the ligamental area (STENZEL 1971; RICHARDSON et al. 1993). The Dutch O. edulis confirmed specimens that were still available (some specimens had been combusted, and are therefore unconfirmed specimens) were placed in the Wageningen Marine Research Reference collection.

\section{Results}

Since the 1970s, no live O. edulis individuals were reported in Belgian and Dutch waters until 2010, when several specimens were found on a navigational buoy located approximately $48 \mathrm{~km}$ off the Belgian coast. After this first finding, $O$. edulis was detected on four confirmed and another two unconfirmed occasions (Table 2).

While O. edulis was detected on the Twin buoy in 2010 ( 853 days in the water) and 2014 ( 729 days), we did not find the species in 2004 (740 days), 2006 (796 days) and 2012 (575 days).

Ostrea edulis was detected on a piece of scrap metal recovered from the wreck of the Kilmore during a scientific diving course on July $19^{\text {th }} 2010$. The non-identified Ostreidae reported from the Kilmore in 2004 (ZINTZEN \& MASSIN 2010), were reinvestigated and the small individuals (6 and $11 \mathrm{~mm}$ ) showed no traces of chomata and thus are not $O$. edulis.

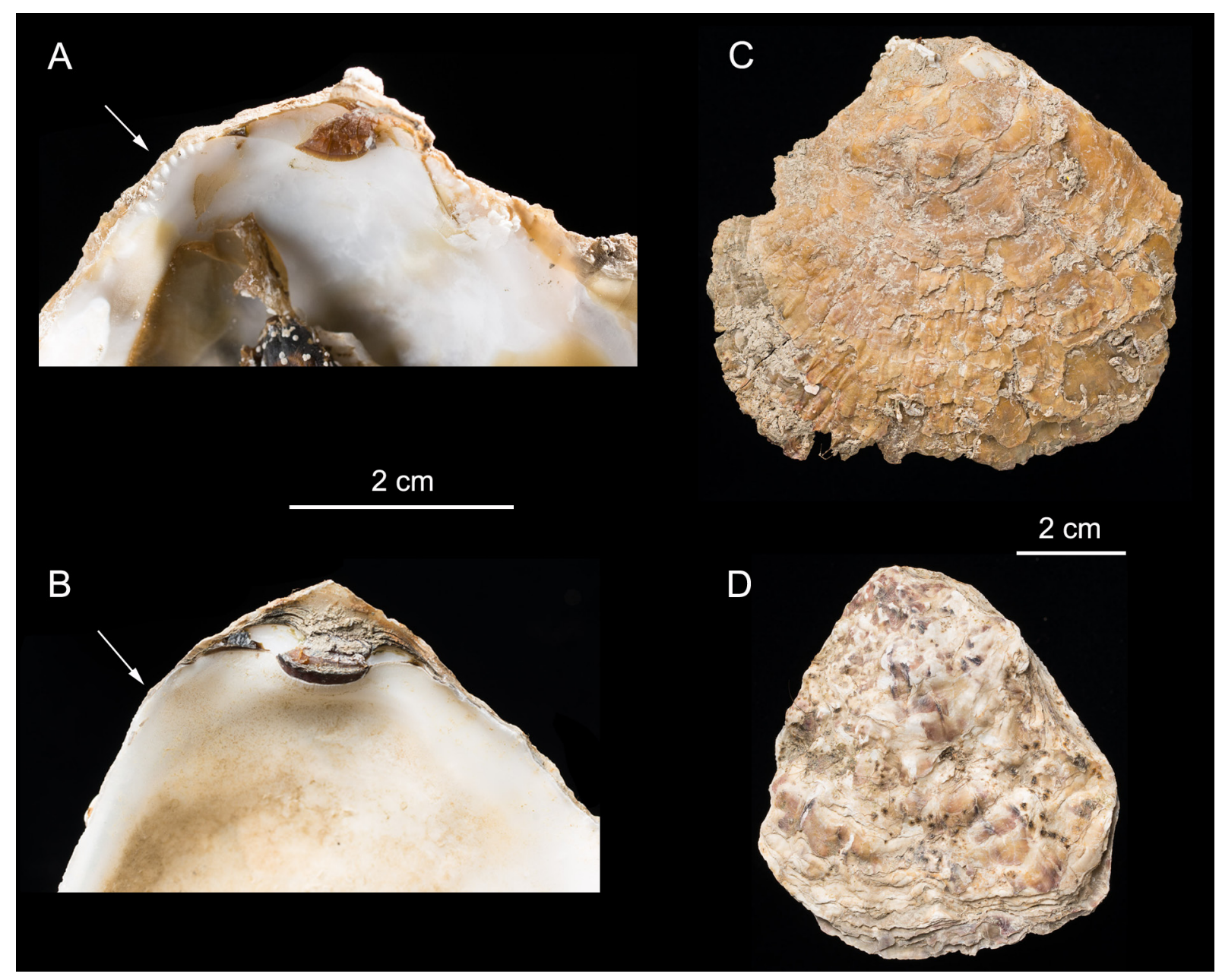

Fig. 1 - Ostrea edulis (Twin Buoy, 5 October 2010) and Crassostrea gigas (groyne Harbour Oostende, 20 March 2017). A-B. Internal view. C-D. Habitus. External view of the upper (right) valve of O. edulis (C) and C. gigas (D). Internal view of the hinge part of the upper (right) valve of $O$. edulis (A) with chomata indicated by a white arrow and C. gigas (B) where the white arrow points to the lack of chomata. 
KERCKHOF F. et al., Recent findings of wild European flat oysters in Belgian and Dutch offshore waters

TABLE 2

Ostrea edulis findings in Belgian and Dutch waters since 2010. Confirmed $=$ confirmed by the presence of chomata; not confirmed $=$ presence of chomata not confirmed (i.e., field observation).

\begin{tabular}{|c|c|c|c|c|c|c|}
\hline Location & Substrate type & $\begin{array}{l}\text { Geographic } \\
\text { coordinates }\end{array}$ & Date collected & $\begin{array}{l}\text { Distance } \\
\text { from coast }\end{array}$ & Size range & Certainty \\
\hline Twin buoy (BE) & steel buoy & $\begin{array}{c}51^{\circ} 32.10^{\prime} \mathrm{N} \\
2^{\circ} 22.70^{\prime} \mathrm{E}\end{array}$ & 5 October 2010 & $48 \mathrm{~km}$ & $40-70 \mathrm{~mm}$ & confirmed \\
\hline Twin buoy (BE) & steel buoy & $\begin{array}{c}51^{\circ} 32.10^{\prime} \mathrm{N} \\
2^{\circ} 22.70^{\prime} \mathrm{E}\end{array}$ & $\begin{array}{l}20 \text { November } \\
2014\end{array}$ & $48 \mathrm{~km}$ & $60-90 \mathrm{~mm}$ & confirmed \\
\hline $\begin{array}{l}\text { Kilmore wreck } \\
\text { (BE) }\end{array}$ & $\begin{array}{l}\text { steel wreck, } \\
\text { scrap }\end{array}$ & $\begin{array}{c}51^{\circ} 23.84^{\prime} \mathrm{N} \\
2^{\circ} 29.87^{\prime} \mathrm{E}\end{array}$ & 19 July 2010 & $27 \mathrm{~km}$ & $35 \mathrm{~mm}$ & confirmed \\
\hline $\begin{array}{c}\text { Christiaan Huygens } \\
\text { wreck (NL) }\end{array}$ & steel & $\begin{array}{c}51^{\circ} 37.044^{\prime} \mathrm{N} \\
3^{\circ} 16.74^{\prime} \mathrm{E}\end{array}$ & observed in 2012 & $14 \mathrm{~km}$ & unknown & $\begin{array}{l}\text { not confir- } \\
\text { med }\end{array}$ \\
\hline $\begin{array}{l}\text { HMS Aboukir } \\
\text { wreck (NL) }\end{array}$ & steel & $\begin{array}{c}51^{\circ} 15.00^{\prime} \mathrm{N} \\
3^{\circ} 40.99^{\prime} \mathrm{E}\end{array}$ & summer 2013 & $42 \mathrm{~km}$ & $125 \mathrm{~mm}$ & confirmed \\
\hline $\begin{array}{l}\text { Offshore windfarm } \\
\text { OWEZ (NL) }\end{array}$ & steel pile & $\begin{array}{c}\mathrm{T} 7: 51^{\circ} 36.43^{\prime} \mathrm{N} \\
4^{\circ} 23.94^{\prime} \mathrm{E} \\
\mathrm{T} 34^{\circ} 51^{\circ} 37.48^{\prime} \mathrm{N}, \\
4^{\circ} 25.96^{\prime} \mathrm{E}\end{array}$ & 2011 & $13 \mathrm{~km}$ & unknown & $\begin{array}{l}\text { not confir- } \\
\text { med }\end{array}$ \\
\hline
\end{tabular}

In Dutch waters a specimen of $O$. edulis was detected in 2012 on the Christian Huygens wreck, attached to an unidentified part of the wreck. The specimen was left in situ and only identified using external morphological characters. Another specimen collected in summer 2013 on the wreck of HMS Aboukir was an empty doublet that had died only recently. The valves were open, exposing the glossy white inside of the shell without any encrustations, making it obviously visible in an otherwise rather drab environment.

\section{Discussion}

\section{Problematic Ostrea edulis detection and identification}

False negative detections may compromise an accurate view on $O$. edulis presence. Oysters can indeed easily be overlooked by divers as their shells are usually fully overgrown by other epifouling organisms (KORRINGA 1951; SMYTH \& ROBERTS 2010), thus masking their presence. This holds true for O. edulis individuals found on the Twin buoy and Christian Huygens wreck, where the specimens were hidden under a thick layer of Jassa turf. Furthermore, being flat and tightly glued to the surface, oysters are often noticed only after the valves are opened. Also the individual on the piece of scrap was not actually detected by the divers and its presence among the epifaunal growth was noted only later when samples were inspected in detail in the lab. The observation that divers do not necessarily detect oysters during routine sampling surveys clearly indicates that visual inspection of epifauna has to be carefully evaluated before conclusions on their absence can be drawn. While oysters were first rediscovered in Belgian and Dutch waters in 2010, they may have been present in the area before then. This assumption is further strengthened by the poor attention that was paid to hard substrate epifauna in the second half of the $20^{\text {th }}$ 
century, when North Sea benthos research was focused on soft sediment infauna and epifauna (e.g., HEIP et al. 1992; REES et al. 2007).

False negative, but especially false positive recordings of $O$. edulis may also be linked to misidentifications. Ostrea edulis and Crassostrea gigas are the only two oyster species with established populations in the North Sea (Oliver et al. 2016), and only the introduced Pacific oyster C. gigas is found abundantly on nearly all marine hard substrates in shallow water (e.g., harbour walls and groynes) or within the intertidal zone (e.g., buoys and windmills) (KERCKHOF et al. 2007; WOLFF 2005; KERCKHOF et al. 2016). In general, adult individuals can readily be identified given that $O$. edulis specimens are relatively flat and round, while $C$. gigas are usually more elongated and cupped. However, morphological plasticity within both species is known to be high (STENZEL 1971) and their external morphology may overlap (Fig. 1). Under certain environmental conditions C. gigas individuals are flat and circular and hence resemble O. edulis at first sight (F. Kerckhof, unpublished data). Oysters from the Prinses Amalia wind farm (the Netherlands) originally identified as $O$. edulis (VANAGT et al. 2013) proved to be $C$. gigas after closer inspection (VANAGT \& FAASSE 2014). Internal inspection for the presence of chomata, indicative for Ostrea, hence is crucial (Fig. 1), and, at least for doubtful specimens, internal inspection of the hinge region is needed for correct identification, as performed in this study.

\section{Possible Ostrea edulis source populations for Belgian and Dutch waters}

While O. edulis is considered virtually extinct in Belgian and Dutch offshore waters, a relict brood stock must still be present in the vicinity. Ostrea edulis larvae stay in the water column for only a short period of about $12-10$ days at temperatures between $18^{\circ} \mathrm{C}$ and $20^{\circ} \mathrm{C}$, even shorter at higher water temperatures (BERGHAHN \& RUTH 2005; KORRINGA 1952), corresponding to a dispersal range of more than ten kilometres (BERGHAHN \& RUTH 2005). Adult O. edulis oysters should hence be present either in the Belgian and Dutch waters, or in the neighbouring marine waters as can be deduced from the successful recruitment described in this paper. While $O$. edulis is no longer cultivated in the area, large wild individuals, caught in the eastern English Channel, are being sold in the harbours of Le Tréport (France) and occasionally Oostende (Belgium) (Kerckhof F., unpublished data) and the species still occurs in the Solent region (HARDING et al. 2016). Feral populations have survived for centuries in Lake Grevelingen and the Oosterschelde (the Netherlands; HoEK 1886; VAN BANNING 1991; DAAN et al. 2013). These three sites could be the sources of the European oysters found in Belgian and Dutch waters. However, the exact origin of the recently found $O$. edulis individuals remains unknown. Given that (1) the offshore part of the Belgian and Dutch water is under the direct influence of clear Atlantic Channel water (M'HARZI et al. 1998; LACROIX et al. 2004) and (2) the residual current in the area is north-eastly (i.e., from the English Channel into the North Sea), it may be expected that the source population of the individuals in Belgian and Dutch offshore waters is to be found in the (eastern) English Channel. The recently discovered mixed Crassostrea - Ostrea oyster bed close to the Brouwersdam in the Netherlands most probably originated from nearby populations in the Grevelingen (SIKKEMA 2016). Further population genetic analyses may provide clarification of the origin of these populations.

\section{Ostrea edulis habitat requirements in Belgian and Dutch waters}

Our findings illustrate that at least artificial hard substrates in offshore waters provide a suitable environment for $O$. edulis recruitment and subsequent growth. Both Belgian sites where $O$. edulis was recently encountered are situated in Atlantic water. This water mass is much clearer than the silt-loaded coastal waters (DAUVIN 2012; BROCKMANN et al. 1990). The historical O. edulis reefs in Belgian and Dutch waters, e.g., on the Hinderbanks (LANSZWEERT 1868) and Central Oyster Grounds (HoEK 1886; MöBIUS 1877), were also in offshore clear Atlantic waters. Clear water seems to be a prerequisite for successful $O$. edulis colonization as high silt concentrations in the water column and on the bottom prevent $O$. edulis larval settlement or smother the larvae shortly after settlement (KORRINGA 1946). Historically certain O. edulis reefs were situated closer to the Belgian and Dutch coastline (HouZIAUX 
et al. 2008; OLSEN 1883), however, the siltation of these waters due to human activities (e.g., dredging and harbour wall constructions) during the last century, as suggested by HoUZIAUX et al. (2011), may have rendered these less suitable for $O$. edulis.

Oysters need a hard substrate to settle and grow. In natural circumstances in Belgian and Dutch waters, this habitat was gravel beds with a certain small amount of silt that also held a large fraction of shell hash, old shells that are suitable for the settling of Ostrea-larvae. The presence of $O$. edulis on Belgian gravel beds was documented by Gilson (HouZIAUX et al. 2008). The present findings of $O$. edulis on artificial hard substrates (i.e., scrap metal of wrecks and buoys) may hence be considered unusual. However, Gilson also collected two hull-fouling O. edulis specimens on the Wandelaar lightship in offshore Belgian waters in 1908. They are lodged in the RBINS collection (HouZIAUX et al. 2008). The current reports (albeit anecdotal) of the presence of Ostrea on buoys may be explained by the need of Ostrea larvae for free space and a smooth surface to settle, which would make heavily fouled objects such as wrecks less suitable for settlement than buoys that are cleaned about once every two years. In both cases where $O$. edulis was detected on buoys (2010 and 2014), the specimens' growth rings hinted towards individuals in their second growing season. This corresponds with settlement shortly after the buoys were newly deployed (June 2008 and May 2012) and hence relatively devoid of epifaunal growth.

While gravel beds are still present in the Belgian and Dutch waters (HOUZIAUX et al. 2008; CoOLEN et al. 2015a), O. edulis reefs have long been gone from this originally natural habitat and even individual $O$. edulis specimens seem no longer to occur on gravel beds in the area. The most obvious explanation for the lack of recovery in its natural habitat may be the heavy bottom-trawling fisheries that operate in these waters, physically disturbing the sediment surface preventing long-lived organisms such as O. edulis from developing to maturity.

\section{Possibilities for natural recovery of Ostrea edulis reefs in Belgian and Dutch waters}

Historical and recent finds of $O$. edulis in Belgian and Dutch waters show that, while $O$. edulis reefs were destroyed about a century ago, hampering subsequent successful recruitments (e.g., Gross \& SмYTH 1946), some O. edulis larvae still reach Belgian and Dutch waters and are able to settle and grow under the current environmental conditions. The most critical environmental condition, however, seems to be the presence of physically undisturbed, natural hard substrate such as gravel and shell hash beds. This raises the question whether exclusion of bottom-disturbing human activities would enable natural recovery of $O$. edulis reefs in Belgian and Dutch waters or whether active re-introduction by transplantation would be necessary. Choosing between the two options is timely given that many North Sea countries are currently making plans for $O$. edulis reef restoration. For example, the feasibility of recovery of native oyster stocks in Dutch waters is being explored at the request of the Dutch government (SMAAL et al. 2015). Also in most other countries surrounding the North Sea similar plans are under investigation such as in UK waters (HARDING et al. 2016; LAING et al. 2005, 2006) and the German part of the North Sea (GERCKEN \& SCHMIDT 2014).

Even if bottom-disturbing human activities were halted near the remaining gravel beds, their condition and extent may prove to be too degraded for $O$. edulis recolonization. Belgian gravel beds for example suffered heavily from the removal of stones by bottom trawlers to clean up so-called "dirty" fishing grounds (HAELTERS et al. 2007). When considering O. edulis reef restoration, stone replacement may be a valid managerial action to upgrade the current physical condition of gravel beds, making them again suitable for $O$. edulis settlement and growth. Such plans are being developed or already exist in several countries, e.g., Belgium (VANDE LANOTTE et al. 2012: Actieplan Zeehond), Denmark (NATURSTYRELSEN 2013: Blue Reef) and the Netherlands (LENGKEEK et al. 2017).

In addition to exclusion of physical disturbance of gravel beds and potential restoration of suitable habitat for $O$. edulis, we suggest an in-depth investigation of the natural recovery potential of $O$. edulis reefs in Belgian and Dutch waters as a potentially valuable alternative to human-mediated reintroduction 
of the species. Reintroducing any species in an area always poses a risk of co-introducing parasites and diseases (e.g., Bonamia ostreae; VAN BANNING 1991) and genetic contamination of the local and hence possibly locally-adapted $O$. edulis population (LAUNEY et al. 2002; SANFORD \& KeLLY 2011). We, however, acknowledge that any natural recovery of the oyster reefs is likely to be slow given $O$. edulis larvae are short-lived and do not disperse over large distances (KORRINGA 1952). Policy initiatives such as the currently negotiated restriction of bottom-disturbing human activities in Belgian and Dutch waters (e.g., Flemish Banks and Cleaver Bank fisheries closures, respectively), could be regarded as hands-on experiments and closely monitored for $O$. edulis reef recovery.

In conclusion, our detection of young European flat oysters proves reproduction still takes place in the southern North Sea and/or the eastern English Channel. This suggests potential for a natural recovery of oyster beds in the area. Successful restoration of the European flat oyster beds, however, strongly depends on the availability of a sufficient number of suitable and undisturbed marine areas, where oysters can settle, grow and reproduce. That would at least imply the exclusion of seabed-disturbing activities such as bottom trawling or sand and gravel extraction. Suitable marine protected areas have to be designated and managed with the specific aim of serving European flat oyster restoration. Furthermore, these populations cannot persist in isolation and therefore the possible connectivity between the restored bed(s) and relict populations that still are present in the southern North Sea and English Channel, has to be assessed. The recently established European-wide Native Oyster Restoration Alliance (NORA) aimed at the restoration of the native European flat oyster beds, with international voluntary representation from nature conservation agencies, science institutes, non-governmental organisations as well as oyster farmers, may significantly contribute to the indispensable cross-boundary approach towards this goal.

\section{Acknowledgements}

The authors acknowledge DAB Vloot (Agentschap Maritieme Dienstverlening en Kust, Flemish Government) for allowing us to inspect the Belgian navigational buoys. Thierry Hubin (Royal Belgian Institute of Natural Sciences) is thanked for making the pictures of Ostrea edulis and Crassostrea gigas. Observations on Dutch wrecks were made during diving expeditions organised by the Dive the North Sea Clean foundation. We thank this organisation and its volunteers for their help. This paper contributes to the feasibility study for the facilitation of European flat oyster colonisation (Ostrea edulis) on behalf of the environmental compensation fund (DG5/MM/HV17005), funded by the Belgian Federal Public Service Environment.

\section{References}

AIROLDI L. \& BECK M.W. (2007). Loss, status and trends for coastal marine habitats of Europe. Oceanography and Marine Biology: An Annual Review 45: 345-405.

https://doi.org/10.1201/9781420050943.ch7

AMARAL V.S.D. \& SimONe L.R.L. (2014). Revision of genus Crassostrea (Bivalvia: Ostreidae) of Brazil. Journal of the Marine Biological Association of the United Kingdom 94: 811-836. https://doi.org/10.1017/S0025315414000058

ANONYmus (1999). Native oyster (Ostrea edulis). Species Action Plan. In: UK Biodiversity Group. Tranche 2 Action Plans. Vol. V. Maritime Species and Habitats. English Nature for the UK Biodiversity Group, Peterborough, UK, 242 pp.

Beck M.W., Brumbaugh R.D., Airoldi L., Carranza A., Coen L.D., Crawford C., Defeo O., Edgar G.J., Hancock B., Kay M.C., Lenihan H.S., LuCKenbaCh M.W., Toropova C.L., Zhang G. \& GuO X. (2011). Oyster reefs at risk and recommendations for conservation, restoration, and management. BioScience 61: 107-116. https://doi.org/10.1525/bio.2011.61.2.5 
KERCKHOF F. et al., Recent findings of wild European flat oysters in Belgian and Dutch offshore waters

BERGHAHN R. \& RUTH M. (2005). The disappearance of oysters from the Wadden Sea: a cautionary tale for no-take zones. Aquatic Conservation-Marine and Freshwater Ecosystems 15 (1): 91-104. https://doi.org/10.1002/aqc.635

Bouma S. \& LeNGKeEK W. (2013). Benthic communities on hard substrates within the first Dutch offshore wind farm (OWEZ). Nederlandse Faunistische Mededelingen 41: 59-67.

Brockmann U.H., LaAne R.W.P.M. \& Postma J. (1990). Cycling of nutrient elements in the North Sea. Netherlands Journal of Sea Research 26: 239-264. https://doi.org/10.1016/0077-7579(90)90092-U

Byers J.E., Cuddington K., Jones C.G., TAlley T.S., Hastings A., LAMBrinos J.G., Crooks J.A. \& WILSON W.G. (2006). Using ecosystem engineers to restore ecological systems. Trends in Ecology and Evolution 21: 493-500. https://doi.org/10.1016/j.tree.2006.06.002

CATTRIJSSE A. \& VINCX M. (2001). Biodiversity of the benthos and the avifauna of the Belgian coastal waters: summary of data collected between 1970 and 1998. Federal Office for Scientific, Technical and Cultural Affairs/Sustainable Management of the North Sea. Federal Office for Scientific, Technical and Cultural Affairs, Brussels, Belgium, 48 pp.

COOLEN J.W.P. (2017). North Sea Reefs. Benthic biodiversity of artificial and rocky reefs in the southern North Sea. PhD-thesis Wageningen University \& Research, Wageningen, the Netherlands, 203 pp.

Coolen J.W.P., Bos O.G., Glorius S., LengKeeK W., Cuperus J., VAN Der Weide B. \& Agüera A. (2015a). Reefs, sand and reef-like sand: A comparison of the benthic biodiversity of habitats in the Dutch Borkum Reef Grounds. Journal of Sea Research 103: 84-92.

https://doi.org/10.1016/j.seares.2015.06.010

CoOlen J.W.P., LengkeEK W., Lewis, G., Bos O.G., van Walraven L. \& VAN Dongen U. (2015b). First record of Caryophyllia smithii in the central southern North Sea: artificial reefs affect range extensions of sessile benthic species. Marine Biodiversity Records 8: 4 pages.

https://doi.org/10.1017/S1755267215001165

DaAn R., De Bruyne R., Wijnhoven S., Kuijper W., FaAsse M., Van Moorsel G., Gmelig MEYLING A. \& VAN LEEUWEN S. (2013). Tweekleppigen -Bivalvia. In: DE BRUYNE R., VAN LEEUWEN S., GMELIG MEYLING A. \& DAAn R. (eds) Schelpdieren van het Nederlandse Noordzeegebied: ecologische atlas van de mariene weekdieren (Mollusca): 47-174. Tirion Natuur/Stichting Anemoon, Utrecht en Lisse.

DAUVIN J.-C. (2012). Are the eastern and western basins of the English Channel two separate ecosystems? Marine Pollution Bulletin 64 (3): 463-471 https://doi.org/10.1016/j.marpolbul.2011.12.010

DEGRAER S., BRABANT R. \& RUMES B. (eds) (2013). Environmental impacts of offshore wind farms in the Belgian part of the North Sea: Learning from the past to optimise future monitoring programmes. Royal Belgian Institute of Natural Sciences (RBINS), Operational Directorate Natural Environment, Marine Ecology and Management Section, Brussels. 239 pp.

DE Vooys C.G.N. (2001). Oestervisserij in de Noordzee ruim honderd jaar geleden. Visserijnieuws special Schaal en Schelpdieren 39: 33.

DE Vooys C.G.N., DAPPer R., VAN DeR MeER J., LAVAlEye M.S.S. \& LindeboOM H.J. (2004). Het macrobenthos op het Nederlands Continentale Plat in de Noordzee in de periode 1870-1914 en een poging tot vergelijking met de situatie in de periode 1970-2000. NIOZ-rapport 2004-2. Nederlands Instituut voor Onderzoek der Zee, Texel, The Netherlands, 76 pp.

Didderen K., LengKeek W., Coolen J.W.P. \& WaArdenburg H.W.W. (2013). Harde substraten en biodiversiteit - Vooronderzoek naar kunstmatige objecten in de Noordzee (NCP). Rapport 12-181, Bureau Waardenburg, Culemborg, the Netherlands, 52 pp. 
EuRopeAn COMMISSION 1992. Council Directive 92/43/EEC of 21 May 1992 on the conservation of natural habitats and of wild fauna and flora (Habitats Directive). Official Journal of the European Communities, L 206/7 - L 206/50.

GERCKEN J. \& SCHMidT A. (2015). Current Status of the European Oyster (Ostrea edulis) and Possibilities for Restoration in the German North Sea. 2014. Bundesamt für Naturschutz, Bonn, Germany, 96 pp.

Gross F. \& SMYth J. (1946). The decline of oyster populations. Nature 157 (3991): 540-542. https://doi.org/doi:10.1038/157540a0

HAELTERS J., KERCKHOF F. \& HOUZIAUX J-S. (2007). De aanduiding van mariene beschermde gebieden in de Belgische Noordzee: een mogelijke uitvoering van OSPAR Aanbeveling 2003/3 door België. Beheerseenheid Mathematisch Model Noordzee/Koninklijk Belgisch Instituut voor Natuurwetenschappen, Brussel, Belgium, 46 pp.

Harding S., Nelson L. \& Glover T. (2016). Solent Oyster Restoration Project Management Plan. Blue Marine Foundation (BLUE), London, UK. 49 pp.

HARRY H.W. (1985). Synopsis of the supraspecific classification of living oysters (Bivalvia: Gryphaeidae and Ostreidae). Veliger 28: 121-158. http://ci.nii.ac.jp/naid/10012666099

Heip C., Basford D., Craeymeersch J., Dewarumez J.M., DörJes J., De Wilde P., Duineveld G., Eleftheriou A., Herman P.M.J., Kingston K., Niermann U., KÜNitZer A., RACHOR E., Rumohr H., SOETAERT K. \& SOLTWEDEL T. (1992). Trends in biomass, density and diversity of North Sea macrofauna. ICES Journal of Marine Science 49: 13-22. https://doi.org/10.1093/icesjms/49.1.13

HOEK P.P.C. (1886). Oestercultuur als vaderlandsche industrie. Album der Natuur 35 (1): 151-170; 209-223; 244-268.

HouziauX J-S., Kerckhof F., Degrendele K., Roche M. \& Norro A. (2008). The Hinder banks: yet an important area for the Belgian marine biodiversity? Belgian Science Policy, Brussels, Belgium, $248 \mathrm{pp}$.

Houziaux J-S., FetTweis M., Francken F. \& Van Lancker V. (2011). Historic (1900) seafloor composition in the Belgian-Dutch part of the North Sea: A reconstruction based on calibrated visual sediment descriptions. Continental Shelf Research 31 (10): 1043-1056.

https://doi.org/10.1016/j.csr.2011.03.010

KERCKHOF F., HAELTERS J. \& GOLLASCH S. (2007). Alien species in the marine and brackish ecosystem: the situation in Belgian waters. Aquatic Invasions 2 (3): 243-257. https://doi.org/10.3391/ai.2007.2.3.9

Kerckhof F., De Mesel I. \& Degraer S. (2016). Do wind farms favour introduced hard substrata species? In: DEGRAER S., BRABANT R., RUMES B. \& VIGIN L. (eds) Environmental impacts of offshore wind farms in the Belgian part of the North Sea: Environmental impact monitoring reloaded: 61-75. Royal Belgian Institute of Natural Sciences, OD Natural Environment, Marine Ecology and Management Section.

KORRINGA P. (1946). The decline of natural oyster beds. Basteria 10: 36-41.

KorRINGA P. (1951). The shell of Ostrea edulis as a habitat. Archives Néerlandaises de Zoologie 10: $32-152$.

KORRINGA P. (1952). Recent advances in oyster biology. The Quarterly Review of Biology 27: 266308 \& 339-365. https://doi.org/10.1086/399023

Lacroix G., Ruddick K., Ozer J. \& LANCElot C. (2004). Modelling the impact of the Scheldt and Rhine/Meuse plumes on the salinity distribution in Belgian waters (southern North Sea). Journal of Sea Research 52: 149-153. https://doi.org/10.1016/j.seares.2004.01.003

LAING I., WALKER P. \& AREA F.J. (2005). A feasibility study of native oyster (Ostrea edulis) stock regeneration in the United Kingdom. Report to Defra and Seafish Industry Authority, CEFAS Lowestoft, UK, 96 pp. 
KERCKHOF F. et al., Recent findings of wild European flat oysters in Belgian and Dutch offshore waters

LAING I., WALKeR P. \& AREA F.J. (2006). Return of the native - is European oyster (Ostrea edulis) stock restoration in the UK feasible? Aquatic Living Resources 19: 283-287.

https://doi.org/10.1051/alr:2006029

LAMBERT L. (1946). Les huîtres des côtes françaises. Pêche maritimes 29: 31-33.

LANSZWEERT E. (1868). Les bancs d'huîtres devant Ostende. Annales de la Société royale malacologique de Belgique: bulletin des séances 3: XVII-XVIII.

Launey S., Ledu C., Boudry P., Bonhomme F. \& NaCiRI-GRAVEN Y. (2002). Geographic structure in the European flat oyster (Ostrea edulis L.) as revealed by microsatellite polymorphism. Journal of Heredity 93 (5): 331-351. https://doi.org/10.1093/jhered/93.5.331

LengkeeK W., Didderen K., Dorenbosch M., Bouma S. \& WaArdenburg H. W. (2013). Biodiversiteit van kunstmatige substraten - Een inventarisatie van 10 scheepswrakken op het NCP. Rapport 13-226. Bureau Waardenburg, Culemborg, the Netherlands, 80 pp.

LengKeek W., Didderen K., Driessen F., Teunis M., Coolen J.W.P, Bos O.G, Vergouwen S.A., RAAiJMAKers T., DE VRIES M.B. \& VAN Koningsveld M. (2017). Eco-friendly design of scour protection: potential enhancement of ecological functioning in designs for scour protection in offshore wind farms. Rapport 17-001.Bureau Waardenburg, Culemborg, the Netherlands, 98 pp.

Mallefet J., Zintzen V., Massin C., Norro A., Vincx M., De Maersschalck V., Steyaert M., DEGRAER S. \& CATTRIJSSE A. (2008). Belgian shipwrecks: hotspots for marine biodiversity (BEWREMABI). Final Scientific Report. Belgian Science Policy, Brussels, Belgium, 155 pp.

M'harzi A., Tackx, M., Daro M.H., Kesaulia I., Caturao R. \& Podoor N. (1998). Winter distribution of phytoplankton and zooplankton around some sandbanks of the Belgian coastal zone. Journal of Plankton Research 20: 2031-2052. https://doi.org/10.1093/plankt/20.11.2031

MöBIUS K.A. (1877). Die Auster und die Austernwirtschaft. Verlag von Wiegandt, Hempel und Parey, Berlin, Germany, 126 pp.

MöBIUS K.A. (1893). Über die Thiere der schleswig-holsteinischen Austernbänke, ihre physikalischen und biologischen Lebensverhältnisse. Sitzungsberichte der königlichen Preußischen Akademie der Wissenschaften zu Berlin (1893) 1: 67-92.

NATURSTYRELSEN (2013). Blue Reef - restoration of stone reefs in Kattegat/Restaurering af stenrev I Kattegat. Naturstyrelsen, Copenhagen, Denmark, 17 pp.

Oliver P.G., Holmes A.M., KilleEn I.J. \& TuRNER J.A. (2016). Marine Bivalve Shells of the British Isles. Amgueddfa Cymru - National Museum Wales. Available from http://naturalhistory.museumwales. ac.uk/britishbivalves [accessed 12 April 2017].

Olsen O.T. (1883). The Piscatorial Atlas of the North Sea, English and St. George's Channels, Illustrating the Fishing Ports, Boats, Gear, Species of Fish (how, where, and when caught), and Other Information Concerning Fish and Fisheries. Taylor and Francis, London.

OSPAR 2009. Background document for Ostrea edulis and Ostrea edulis beds. Biodiversity Series 428. OSPAR Commission, 22 pp. Available from https://qsr2010.ospar.org/media/assessments/Species/ P00428_ostrea_edulis_and_beds.pdf [accessed 29 January 2018].

RAPPÉ G. (2008). De Zee van Toen: Een historisch-ecologische verkenning van de zuidelijke Noordzee (1930-1980), uit de mond van Vlaamse vissers. Provincie West-Vlaanderen, Brugge, Belgium, 463 pp.

REes H.L., EgGleton J.D., RACHOR E. \& VANDEN BERGHE E. (eds). (2007). Structure and dynamics of the North Sea benthos. ICES Cooperative Research Report 288, 258 pp.

Richardson C.A., Collis S.A., EKARATnE K., DARE P. \& Key D. (1993). The age determination and growth rate of the European flat oyster, Ostrea edulis, in British waters determined from acetate peels of umbo growth lines. ICES Journal of Marine Science, 50 (4): 493-500.

https://doi.org/10.1006/jmsc.1993.1052 
SANFORD E. \& KELLY M.W. (2011). Local adaptation in marine invertebrates. Annual Review of Marine Science 3: 509-535. https://doi.org/10.1146/annurev-marine-120709-142756

SiKKEMA A. (2016). European flat oysters return to North Sea. Resource 11 (8): 8.

SmaAl A.C., Kamermans P. VAn DeR HaVe T.M., Engelsma M.Y. \& SAS H. (2015). Feasibility of Flat Oyster (Ostrea edulis L.) restoration in the Dutch part of the North Sea. Report / IMARES Wageningen UR C028/15), IMARES, Yerseke, The Netherlands, 58 pp.

SMYth D. \& RoBerTs D. (2010). The European oyster (Ostrea edulis) and its epibiotic succession. Hydrobiologia 655: 25-36. https://doi.org/10.1007/s10750-010-0401-x

Stenzel H.B. (1971). Oysters. In: Moore R.C. (ed.) Treatise on Invertebrate Paleontology. Part N, Vol. 3, Mollusca 6, Bivalvia: i-iv, N953-N1224, 153 figs. Geological Society of America and University of Kansas Press, Boulder, Colorado and Lawrence, Kansas, USA.

Tesch J.J. (1910). De Physische Gesteldheid der Noordzee. Tijdschrift van het Nederlandsch Aardrijkskundig Genootschap: verslagen en aardrijkskundige mededeelingen 27: 702-740.

VAnagt T. \& FAasse M. (2014). Development of hard substratum fauna in the Princess Amalia Wind Farm. Monitoring six years after construction. eCOAST Report 2013009, eCOAST, Oostende, Belgium, $63 \mathrm{pp}+$ annexes.

Vanagt T., Van De Moortel L. \& FaAsse M. (2013). Development of hard substrate fauna in the Princess Amalia Wind Farm. Monitoring 3.5 years after construction. eCOAST report 2011036. eCOAST, Oostende. 47 pp. + annexes.

VAN BANNING P. (1991). Observations on bonamiasis in the stock of the European flat oyster, Ostrea edulis, in the Netherlands, with special reference to the recent developments in Lake Grevelingen. Aquaculture 93 (3): 205-211.

VAN BENEDEN E. (1883). Compte rendu sommaire des recherches entreprises à la Station biologique d'Ostende pendant les mois d'été 1883. Bulletin de l'Académie Royale des Sciences, Littérature et Beaux-Arts de Belgique $3^{\text {ième }}$ Série 6 (11): 458-483.

Van Lancker V., Baeye M., Montereale Gavazzi G. \& Van Den Eynde D. (2016). Monitoring of the impact of the extraction of marine aggregates, in casu sand, in the zone of the Hinder Banks. Scientific Report 3 - January - December 2015 and Synthesis for the period 2011-2015. RBINS-OD Nature, Brussels. 84 pp. +5 annexes.

VANDE LanotTe J., RaBaut M. \& Bossu P. (2012). Actieplan zeehond, van defensief naar offensief milieubeleid in de Noordzee. Brochure, Minister van de Noordzee, Brussels, Belgium, 15 pp.

VAN DER STAP T., COOLEN J.W.P. \& LindeBOOM H.J. (2016). Marine fouling assemblages on offshore gas platforms in the southern North Sea: Effects of depth and distance from shore on biodiversity. PLoS One 11 (1): e0146324. https://doi.org/10.1371/journal.pone.0146324

VAN GINKEL R. (1996). The abundant sea and her fates: Texelian oystermen and the marine commons, 1700 to 1932. Comparative Studies in Society and History 38 (2): 218-242.

WolfF W.J. (2005). Non-indigenous marine and estuarine species in The Netherlands. Zoologische Medelingen Leiden 79 (1): 1-116.

ZINTZEN V. \& MASSIN C. (2010). Artificial hard substrata from the Belgian part of the North Sea and their influence on the distributional range of species. Belgian Journal of Zoology 140 (1): 20-29.

YONGE C.M. (1966). Oysters. Collins, London, UK, 209 pp.

Manuscript received: 27 November 2017

Manuscript accepted: 16 January 2018

Published on: 12 April 2018

Branch editor: Isa Schön 